\title{
Faglig vs. informationsrelateret læring
}

\author{
Integrative elementer i fænomenografiske, sociokulturelle \\ og diskursanalytiske teorier om informationskompetence
}

\author{
Af Volkmar Engerer
}

\begin{abstract}
I foreliggende artikel tages der udgangspunkt i teoretiske forsøg på at karakterisere forholdet mellem disciplinoer-universitetsbaseret og informationsrelateret loering (informationskompetence). Der skelnes mellem (1) generisk-disciplinuafhoengige, (2) disciplinrelaterede og (3) integrative tilgange til at modellere forholdet mellem informationsbrug og faglige laeringsaktiviteter. Sidstncevnte integrative tilgang forener faglig og informationsrelateret loring $i$ en kohcerent og meningsgivende proces og reprcesenterer derfor den foretrukne måde hvorpå man når frem til en syntese af universitets- og biblioteksbaserede laereprocesser. Integrative tilgange beskrives vha. to analytiske integrative kendetegn (situation og individets erfaring/koncepter) og undersøges i tre grupper af teorier, som alle sigter mod overvindelse af det generiske paradigme i informationskompetenceforskningen (fcenomenografiske, sociokulturel-praksisteoretiske og diskursanalytiske tilgange, herunder Kritisk pcedagogik). Det viser sig, at disse tre teoretiske grupperinger reprasenterer integrative kriterier i forskellig grad, med fcenomenografien som "mest integrerende" (realiserer begge kriterier), og diskursteorien som mindst, fordi den, idet der abstraheres både fra den aktuelle situations indlejring og individets (skiftende) erfaringer med fonomener, ikke har
\end{abstract}

Volkmar Engerer, lektor,

Det Informationsvidenskabelige Akademi

Københavns Universitet (rhd237@iva.ku.dk) fokus på nogle af kriterierne. Sociokulturelle teorier befinder sig i midten, idet individets erfaring af informationskompetence nedtones i forhold til fanomenografien, mens en stcerk fokus på situationelle elementer bibeholdes. Artiklen slutter med nogle praktiske konsekvenser af et "integrativt informationskompetencebegreb" for bibliotekernes undervisningstiltag $i$ informationskompetence.

\section{Introduktion: faglig og informationsrelateret læ- ring}

I denne artikel ${ }^{1}$ skal der åbnes op for en diskussion om læring og dets dimensioner i en forskningsbiblioteks- og universitetssammenhæng. I denne forbindelse er informationskompetence nøgleordet, fordi det er her, hvor den læringsmæssige skellinje mellem "egentlig" læring (disciplinær læring) og den læring, der almindeligvis forbindes med biblioteket, bedst kommer til syne. Den teoretiske kløft mellem informationsrelateret læring på den ene side og "overordnet"/"faglig" læring på den anden relaterer sig til modsætningen mellem informationskompetence som bibliotekarisk kunnen versus faglig kompetence/ læring, som foregår i de højere uddannelsesinstitutioner og betragtes som det egentlige formål med uddannelsen. For at få belyst dette skel skal der ses nærmere på nogle forsøg på at knytte biblioteksbaseret informationskompetence til universitetsbaserede læreprocesser og drøftes, hvilken status teorier om informationskompetence tildeler læring i det hele taget. Der er således ikke fokus på den praktiske omsætning af informationskompetence, fx i form af 
biblioteksundervisning eller andre læringsrelaterede tiltag af professionelle informationsspecialister ( Julien \& Williamson, 2011). Dog skal der i den sidste del af denne artikel skitseres nogle konsekvenser af læringsrelaterede, "integrative" opfattelser af informationskompetence for universitetsbibliotekernes undervisningstiltag og forhold til undervisere og studerende.

Der er i litteraturen flere holdninger til, hvordan forholdet mellem informationskompetencer og universitetsfaget skal udformes. Indledningsvis skal der peges på to modpositioner. Den første karakteriseres som den "generiske" strategi, da den postulerer eksistensen af "rene" og generelle informationskompetencer, som i princippet kan læres (men nok ikke udøves) uafhængigt af fagligt indhold. Den anden, "disciplinrelaterede" tese betragter informationskompetencer som altid værende knyttet til et fag og et fags traditioner, som danner den relevante læringskontekst; informationskompetencer er i dette perspektiv specifikt og udvikles altid sammen med faglige kompetencer. Udover disse to modpoler findes der en tredje måde at sætte informationskompetence og faglig læring i forhold til hinanden, nemlig ved at de to sfærer betragtes som teoretisk-analytisk adskilte, men i praksis forbundne læringsprocesser, som indgår, så at sige, i en syntese. Denne "integrative" tilgang, som her er den præfererede, skal på de næste sider udvikles og konkretiseres nærmere, da den danner baggrund for en diskussion af en række teorier, som, på en central måde, realiserer integrative komponenter.

\section{Generiske og disciplinrelaterede vinkler på infor- mationskompetence}

Den generiske strategi bygger på en universel bibliotekarisk "værktøjskasse" (se hertil et forsøg med en datadase-tjekliste beskrevet i Engerer \& Stadsgaard, 2011) og fremhæver dens situationsuafhængige anvendelighed, hvor den informationssøgende ikke har brug for færdigheder, der er specielle for en bestemt kilde eller situation. Brugeren skal til gengæld lære de generelle processer og principper for udvælgelse, søgning og bearbejdning af indhold og information (Bawden, 2001, s. 240; Williams, 2005), som kan anvendes uafhængigt af fagligt indhold, i mange situationer i fremtiden, muligvis hele livet (Lupton, 2008, s. 29). ${ }^{2}$
Det generisk funderede begreb på informationskompetence knyttes til læring i en traditionel BDI- (biblioteks-, dokumentations- og informationskundskab) sammenhæng ${ }^{3}$ ved at pege på informationsbrugerens kompetencer og færdigheder i hans/hendes omgang med information, fra identifikation af behovet hen til at finde information, evaluere den og arbejde videre med den mht. at tilegne sig viden eller opnå problemløsning. Denne karakterisering, som støtter sig på nogle autorative "standarder" inden for biblioteksområdet som ACRL fra 2000 (se Engerer \& Thestrup, 2009, s. 6-8, og litteraturhenvisninger der) og de ældre ALA-standarder fra $1989,{ }^{4}$ har været udsat for kritik især i de sidste 10 år fra nogle mere sociologisk-fænomenologisk inspirerede tilgange, som vi kommer udførligt ind på senere. Kritikken retter sig fx mod den hidtil fremherskende "listetænkning", som kommer, som der påpeges af modstanderne, til udtryk i informationskompetencestandarderne (Bawden, 2001, s. 239; Bruce \& Hughes, 2010, s. A2; Kopp \& Olson-Kopp, 2010, s. 59; Owusu-Ansah, 2003, s. 225, under henvisning til Kuhlthau).

Den disciplinrelaterede strategi bygger ligesom den generiske tilgang på en "værktøjskasse", men en, der skifter udseende og indmad, afhængigt af på hvilket område og i hvilken disciplin, der skal "arbejdes" (Kautto \& Talja, 2007; Limberg, Sundin, \& Talja, 2012, s. 112). Selvom der har været plæderet for, ud fra et praktisk syn, at "mikse" generiske og disciplinbundne former for læring og undervisning (Peacock, 2005 , s. 162, 164), er der gode argumenter for, at generisk læring, set som tilegnelse af disciplinuafhængige færdigheder, ikke findes i den akademiske virkelighed. En kvalitativ, ikke repræsentativ undersøgelse af Woolwine (2010) viste (se også Kautto \& Talja, 2007), at de mest gængse komponenter i et generisk-faguafhængigt koncept af informationskompetence, nemlig aktualitet ('timeliness'), autoritet, bias/ ensidighed, verificerbarhed og logisk konsistens, på ingen måder havde konstant betydning i de enkelte fag og fagområder (Woolwine, 2010, s. 170).

Det er dermed, ifølge den disciplinrelaterede strategi, selve disciplinen, som i høj grad sætter standarden for kritisk evaluering af materialer. Tilegnelsen af denne viden og indlæring kan kun foregå ved, at den studerende selv producerer akademiske produkter og engagerer sig i fagspecifikke aktiviteter, fordi kriterierne er knyttet til skabelse af hensigtsmæssige 
resultater i disciplinen, som Woolwine (2010, s. 181) fremhæver.

\section{Kendetegn af integrative opfattelser af informa- tionskompetence og nogle metodiske bemærknin- ger}

Der skal i det følgende ses nærmere på, hvordan et samlet syn på disciplin- og informationslæring kommer til udtryk i sådanne teoretiske retninger, der, i en vis forstand, transcenderer det generiske og det disciplinære paradigme (til et lignende argument, se Limberg et al., 2012, s. 118). Sådanne tilgange, som her betegnes som "integrative", udvælges efter nogle kriterier, som direkte eller indirekte fremgår af vores kritiske diskussion af generiske elementer i informationskompetenceforskning. Integrative teorier har således grundlæggende det til fælles, at de

1. udfordrer synet på informationskompetence som mængde af generiske færdigheder (Limberg et al., 2012, s. 118) og

2. er karakteriseret ved en udpræget sammenvævning af informationskompetence med disciplinært læreindhold (sml. disciplinrelaterede komponenter ovenfor). En gennemgående fokus lægges endvidere

3. på én integrativ læringserfaring hos individet, der naturligt bevæger sig mellem to læringsdomæner (fx universitetet og biblioteket) uden at skulle "skifte modus" ved overgangen fra det ene til det andet. I integrative tilgange betragtes læring derfor som paraplybegreb, der dækker, ganske i integrativ forstand, information både som disciplinær genstand (som skal forstås) og som objekt at håndtere med.

Integrative tilgange til informationskompetence kan beskrives vha. to hovedkendetegn, der hver for sig adskiller dem fra generiske paradigmer: a) den sociale situation og b) individets erfaring af den. Idet nogle integrative tilgange inddrager decideret komponenterne af selve situationen, den informationss $\varnothing$ gende/lærende agerer i (Limberg et al., 2012, s. 109), imødekommes der bl.a. nogle af desiderata af den nævnte disciplinrelaterede forskning i informationskompetence. Integrative tilgange, som inddrager situationens komponenter i teoridannelsen, dækker både praksisteoretiske elementer (se afsnit om sociokulturelle tilgange og praksisteorier) og kommer også til syne i fænomenografisk inspireret tænkning (sml. det "situative" vindue, se afsnit om GeST senere i artiklen). Kriterium (b) mener et hensynstagen, både $\mathrm{i}$ teoridannelse og metodevalg, til individets egne konceptioner af informationsprocessen og dets opfattelse af egne og andres informationskompetencer. Dette kendetegn grunder i et individuelt-konceptuelt udgangspunkt, som især fænomenografisk inspirerede teorier baserer sig på (sml. det følgende afsnit).

Disse to kriterier vil tjene som orienteringspunkter i den følgende gennemgang af vigtige integrative paradigmer i den moderne udforskning af informationskompetence, nemlig

1. fænomenografiske analyser,

2. sociokulturelle og praksisteoretiske tilgange og

3. diskursanalytisk teori, inkluderende Kritisk pædagogik (en lignende, men måske mere restriktiv opdeling foretages i Limberg et al., 2012).

Konstruktivistiske principper af læring, som har en lang tradition i analyser af informationskompetence og biblioteksrelaterede læreprocesser (Grassian \& Kaplowitz, 2009, s. 32ff.; Julien \& Williamson, 2011, s. 4; Lindquist \& Long, 2011; Littlejohn, 2005; Walton \& Hepworth, 2011; sml. også Williams, 2005), knytter sig i høj grad til Carol Kuhlthaus arbejder (sml. især Kuhlthau, 2004) og fortjener en adskilt behandling. Konstruktivistismen må derfor udelades i denne artikel. ${ }^{5}$

\section{Den fænomenografiske tradition i informations- kompetenceforskning}

Fænomenografisk inspireret forskning i informationskompetence (for et godt overblik sml. Limberg et al., 2012, s. 98-102) har mht. de ovennævnte tre integrative kriterier en særlig status, da den i teori og metode tilgodeser begge kriterier, situation og individuel erfaring, og dermed kan opfattes som et forholdsvis dækkende forskningsparadigme i forhold til informationskompetence.

Den fænomenografiske tradition er især forbundet med kriterium $b$ ), individets erfaring, idet et centralt begreb i fænomenografiske tilgange (sml. Bruce, 1998, s. 27; Lupton, 2008, s. 30-32) er en "konception" (eller "erfaringer"), som er en måde at erfare/opfatte verden på, og som konstrueres som intern relation mellem mennesker (subjekter) og noget i verden (objekt). Relationen mellem subjektets konceptioner 
og ting i verden kan ses som en fænomenografisk rekonstruktion af forholdet mellem b), individet, og a), den sociale situation. "Fænomenet", et andet grundbegreb i fænomenologisk inspirerede teorier, beskrives i forhold til disse konceptioner og fremstår som et kompleks af relevante subjekt-objekt-relationer.

Konceptionerne, i fænomenologisk forstand, beskriver dermed informationskompetence som fænomen, som det opfattes af mennesker (Bruce, 1998, s. 27). Læringens basale rolle i fænomenografi, som vi vil komme nærmere ind på, er grundlagt i bogen Learning and awareness (Marton \& Booth, 1997), som er hovedreferencen indenfor den fænomenografiske skole.

I det følgende skal der præsenteres nogle udvalgte tilgange, som alle i større eller mindre grad er inspirerede af fænomenografisk tænkning, for det første for at illustrere bredden af forskningen som et fænomenografisk grundlag afføder, og, for det andet, at give et fingerpeg om, i hvilken grad integrative aspekter indgår hos de enkelte forfattere. Der ses i det følgende nærmere på GeST-modellen, Bruces fænomenografisk forskning ("7 ansigter" og "informed learning") og Luptons integrative ideer af læring i forhold til informationskompetence.

\section{GeST-modellen}

Som udgangspunkt og illustration tages der afsæt i GeST (Generic-Situational-Transformational)-modellen, som er et forsøg på at give de traditionelle, færdighedsbaserede "listeopfattelser" af informationskompetence en ny, integrativ berettigelse og en teoretisk plads i et sammenhængende og mere omfattende koncept af informationskompetence. Dette sker ved hjælp af en videnskabelig vinduesmetafor, hvor den traditionelle færdighedsopfattelse placeres i et "generisk vindue", som så i et andet skridt bliver del af et "situeret vindue". Information er, set fra dette vindue, personlig, intern og subjektiv og informationskompetence evalueres i forhold til dens betydning for individet og den sociale gruppe (Lupton \& Bruce, 2010, s. 12); dette perspektiv rummer både de situationelle og de individuelle aspekter i en ageren med information. I en sidste bevægelse placeres det situerede vindue, sammen med det generiske, i det såkaldte "transformative vindue" (Lupton, 2008, s. 29; Lupton \& Bruce, 2010, s. 13; Williams, 2005, s. 50), hvor informationspraksisser bruges til at forandre ('transformere') én selv og samfundet. Dette skridt har for øvrigt tydelige korrespondenser til et syn på informationskompetencer, som også kommer frem i Kritisk pædagogik (se et senere afsnit) og diskursanalytisk inspirerede studier af informationskompetence (Limberg et al., 2012, s. 110-114).

Inden for GeST-modellen kan der defineres forskellige forudsætnings- og inklusionsrelationer mellem de tre vinduer, hvad der gør informationskompetence til et struktureret, veldefineret og bredtfavnende videnskabeligt koncept.

Denne integrative opfattelse af informationskompetence, som den kommer til udtryk i GeST-modellen, knytter ikke kun, som vist ovenfor, individ og situation i deres forhold til information og informationskompetence sammen, men sætter informationskompetence eksplicit i forbindelse med at bruge information til at lære (Lupton \& Bruce, 2010, s. $3)$, idet læring eksplicit relateres til de tre vinduer (Lupton, 2008, s. 29). Inden for det generiske vindue betyder læring tilegnelsen af færdigheder og processer. Informationskompetence er læringens genstand, som beskrevet indledningsvis som "generisk strategi". Det situerede vindue perspektiverer læring som erfaringen af autentiske praksisser i personelle, professionelle, disciplinært-faglige kontekster, hvad der sætter informationskompetence i forbindelse både med praksisteoretiske antagelser (se afsnittet om praksisteorier) og de tidligere nævnte "disciplinære strategier". Og til sidst, gennem det transformative vindue, udfordrer læring et hidtil velkendt syn og status quo, og korresponderer dermed med diskursanalytisk og kritisk tankegods. GeST-modellen er dermed integrativ på flere måder, for det første idet den bygger en neksus mellem to læringsdomæner (faglig og informationsrelateret), og for det andet ved ellers modstridende opfattelser af informationskompetence kommer til deres ret under ét tag og ikke udelukker hinanden længere. Til sidst skal der igen nævnes, at begge integrative kriterier, situation og individ, realiseres i denne tilgang.

\section{Christine Bruces fanomenografiske studier af infor- mationskompetence}

En konkret anvendelse af fænomenografisk tænkning på informationskompetence er Bruces "syv ansigter" (Bruce, 1998), hvor der udvikles en relationel forståelse af informationskompetence, ikke færdighedsbaseret og behavioristisk, som de kritiserede "listetilgange". Informationskompetence paralleliseres med læring, som er en del af den enkeltes erfaringshori- 
sont (Bruce, 1998, s. 26). Den relationelle tilgang til informationskompetence sætter ikke tilegnelsen af færdigheder i forgrunden, men fokuserer derimod på de lærendes mulighed for at spejle deres egen udvikling i termerne af de ovennævnte syv ansigter (eller "konceptioner" i fænomenografisk terminologi). Bruces forskning, og fænomenografiske metoder i det hele taget, sætter lys på variation og forskellighed af menneskers konceptioner af informationskompetence (Limberg et al., 2012, s. 99).

En nyere integrativ tilgang med fænomenografisk tilsnit gemmer sig bag navnet "Informed learning" (Bruce \& Hughes, 2010). Her undersøges, hvordan informationsrelaterede aktiviteter forholder sig til læring, både disciplinær og informationskompetenceorienteret. Studerende lærer, ifølge forfatterne, om og med information gennem en refleksiv proces, hvor deres opmærksomhed bliver rettet mod selve læringen. Ud fra den fænomenografiske optik (Bruce $\&$ Hughes, 2010, s. A3) skelnes der mellem lineære, cykliske og simultane tilgange til informationsbrug (Bruce \& Hughes, 2010, s. A4). Den lineære læringserfaring er 'først at søge information, bagefter at lære fra den'. Ved den cykliske modus gennemføres en første lineær sekvens ('søge > lære'), som afsluttes med at identificere behovet for mere information til yderligere læring; derefter følger en ny lineær sekvens 'søge > lære'. I den simultane modus opfattes informationsbrug og læring ikke længere som adskilte aktiviteter. De studerende betragter sig, som Bruce \& Hughes påpeger, selv som lærende, mens de er optaget med at interagere med information (Bruce \& Hughes, 2010, s. A4). De studerende er sig i deres læringshandlinger de forskellige aspekter af informationsbrug bevidst, $\mathrm{fx}$ at lokalisere, finde information eller informationskilder, eller at bygge en personlig vidensbase op.

Læring er, for en informationsbruger, dermed ofte ikke en proces, der begynder når bogen læses og slutter når en litteraturhenvisning skal slås op i bibliotekskataloget; læring forbinder disse to processer og subsumerer, som den simultane modus implicerer, både biblioteks- og uddannelsesmæssige processer under én kohærent læringsaktivitet. Derudover findes i denne studie også nogle interessante bemærkninger om interaktion mellem bruger og elektronisk ressource, hvor især den simultane modus kommer til at præge læreerfaringen (Bruce \& Hughes, 2010, s. A5). ${ }^{6}$
Luptons syntese af disciplin- og informationskompetencelcering

Lupton (2008, s. 11, 35f) gør et decideret forsøg på at forbinde disciplinære og informationskompetencerelaterede aktiviteter under ét læringsbegreb. Der skelnes under henvisning til Marton \& Booth (1997, s. 84f) på det første niveau mellem (I) læringens indhold (læringens "hvad", dens emne og direkte objekt) og (II) læringsprocessen (læringens "hvordan", tilgang til læringen). På det andet niveau spaltes processen (II) i to komponenter, (IIa) læringsakt og (IIb) læringens indirekte objekt, altså det, som akten (IIa) er rettet imod, dvs. de kapaciteter, som den lærende forsøger at udvikle. En vigtig antagelse er, ifølge den fænomenografiske tradition, at læringsindhold (I) og læringsproces (II) er forbundet med hinanden og dele af det samme fænomen: Der er ingen læring af noget (I) uden en læringsproces (II), ligesom der ikke kan være en læringsproces (II) uden en genstand for læring (I) (Lupton, 2008, s. 35). Vha. disse skel kan Lupton tilordne informationsrelateret læring en plads i forhold til disciplinær læring.

Disciplinær læring svarer ifølge Lupton til læringsindhold (I), dens direkte objekt ("hvad der skal læres"), mens informationskompetence situeres på læringens processide ("hvordan") (II) og får derfor karakteren af en facilitator for den studerendes læring, at finde information (II) til et emne (I), sml. Lupton (2008, s. 11). I forhold til læringsprocessens underkategorier, læringsakt (IIa) og dens indirekte objekt (IIb), kan der siges, at alle informationshåndterende aktiviteter (ikke informationsfortolkende, som hører til læringens indhold (I)) regnes til læringsakt (IIa), mens informationskompetencerelaterede færdigheder indgår i læringens indirekte objekt (IIb):

I laeringsprocessen håndteres information (IIa) med målet at støtte den indholdsmoessige loering (I), imens der på en "indirekte" måde akkumuleres og udvikles informationsrelaterede kapaciteter (IIb), som effektiviserende kan indgå i fremtidige laeringsakter (IIa).

Motivationen, og det er ikke et begreb, Lupton bruger i denne sammenhæng, er i alle tilfælde det direkte objekt ("direkte motivation"), det egentlige læringsindhold (I), hvorimod, hvis man inddrager Bruce \& Hughes' (2010) resultater om læringens bevidsthed (se ovenfor), kan informationskompetencer som indirekte objekt (IIb) være i højere eller mindre 
grad bevidste og derfor i højere eller mindre grad motivationsskabende ("indirekte motivation").

På denne integrative baggrund, hvor individ og læresituation danner en enhed og disciplin og informationshåndtering samles under ét læringstag, kan spørgsmålet om diskrepansen mellem informationskompetence og disciplinært indhold, som er den gennemgående tråd i artiklen, genoptages og de to første tilgange til problemet, den generiske og disciplinrelaterede strategi, belyses mere præcist. Mens den disciplinære strategi respekterer det faglige indholds fortrinsret i position (I) og holder sig inden for standardkonfigurationen med informationskompetence på læringens processide (II), promoverer den generiske tilgang den informationskompetencerelaterede læringsproces fra (II) til (I) - gør den til et direkte læringsobjekt (Lupton, 2008, s. 35). Hvis man forbliver i denne læringsramme, vil det svare til "læring uden indhold", idet der ikke findes læring per se eller tænkeevner i sig selv, uden at de knyttes til en genstand for læring eller tænkning (Lupton, 2008, s. 35).

\section{Sociokulturelle perspektiver på informationskom- petence og praksisteorier}

Mens fænomenografisk inspirerede tilgange på en realistisk måde relaterer individ og situation i en læringssammenhæng, idet de modellerer den af den lærende erfarbare neksus mellem fag og information, henholdsvis sig selv og en læresituation, fokuserer andre teoretiske retninger i højere grad på læringspotentialet, der udelukkende ligger i situationen, herunder alle værktøjer, der kan anvendes til lærings- og kommunikationsformål. Tilgange med denne udprægede vinkel på situationens komponenter (og deltagere) og teknologiske dimensioner betegnes som "sociokulturelle", hvor gruppen af praksisteorier også skal henføres til.

Sociokulturel tænkning (sml. for det følgende Limberg et al., 2012, s. 104-109) angår forholdet mellem individ og forskellige former for kollektive praksisser og retter sig imod tilegnelse af kommunikativekonceptuelle og tekniske værktøjer, der tjener som middel for formidling i sociale praksisser. Social aktivitet er i et sociokulturelt syn grundlæggende medieret gennem tekniske værktøjer, hvor alle teknologier og medier, samt deres materialitet, som er knyttet til information, er relevante. Struktur og materialitet bestemmer, hvordan interaktion udformes. Informati- onssøgning sker gennem en sekvens af sociale aktiviteter og er indlejret i sociale praksisser.

Ud fra et sociokulturelt perspektiv har informationssøgning altid et bestemt formål i en bestemt praksis (at skrive en artikel, ...). Læring er dermed grundlæggende situeret og foregår vha. deltagelse og kommunikation:

"[...] information literacy implies learning to communicate appropriately within a specific practice." (Limberg et al., 2012, s. 104)

I denne forbindelse nævnes tit Lave \& Wengers bog Situated learning (Lave \& Wenger, 1991), som placerer læring i praksisfællesskaber ('communities of practice'). Praksisteorier og praksisteoretiske tilgange til informationskompetence i særdeleshed skal kunne håndtere de forskellige kontekster, et informationssøgende individ indgår i, og placerer ham/hende i "et medlemskab af et praksisfællesskab" (Schreiber, 2011, s. 96). Denne egenskab forbinder praksisteorier og sociokulturelle analyser af informationskompetence med situationsrelaterede opfattelser ( $\mathrm{sml}$. kriterium a).

Schreiber (2011, s. 97) fremhæver en række fællestræk for praksisteorier. "Praksis" er handling, tænkning og socialt liv sammen, der er ikke nogle "foretrukne" væremåder. Kropslige og intellektuelle handlinger, "åndens og håndens arbejde", er lige vigtige. Ting (redskaber, artefakter) indgår eksplicit i praksisbegrebet, forståelser er "medieret gennem tingene". Praksis konstituerer sociale fænomener (viden, mening, ...), og sociale forståelser konstituerer aktiviteterne i en praksis. "Praksisserne" er i sig selv konteksten, der er ingen ramme, der ligger bagved, men er noget der hele tiden skabes. Praksisteoretikere undgår endvidere de store abstrakte teorier, målet er at beholde en konkrethed og nærhed til praksis. Individer er ikke selvstændige størrelser der er hævet op over det materielle/handlingsmæssige niveau ("individualisme"). Med andre ord: individet går op i situationen, er en del af den ligesom alle andre elementer som samtalepartnere, personer, der lytter og overværer situationen, og alle artefakter og objekter, som bruges af deltagerne. For vores kriterier for integrative kendetegn i teorier om informationskompetence betyder det, at kriterium b), individet og dets erfaringer, fremstår som nedtonet i praksisteoretiske 
tilgange og erstattes af en udpræget fokus på situationen (a).

Sammenhæng mellem praksisinspirerede tilgange og informationskompetence og læring tematiseres fx af Lipponen (Lipponen, 2010, s. 55f). Lipponen skelner mellem to konceptioner af læring, læring $i$ en tilegnelsesramme ("learning as acquisition of knowledge") og læring i en deltagelsesramme (Lipponen, 2010, s. 53). Læring i en deltagelsesramme, som i høj grad korresponderer med praksisteoretiske antagelser, har som udgangspunkt, at al informationsadfærd finder sted i større sammenhænge, fx kan meningen af en databasesøgning ligge $i$ at afslutte et speciale. Der er altid overordnede problemløsningsprocesser, som gør en søgning til en del af noget større:

"Searching for information, problem-solving and learning are inseparable processes" (Lipponen, 2010, s. 54).

Fokus ligger ikke længere på den enkeltes "hoved", men på interaktion, diskurs og deltagelse. Læring er noget, der opstår i deltagelsesprocessen, typisk i praksisfællesskaber, som er grupper af mennesker, der står i tæt interaktion, arbejder på et bestemt felt og har udviklet et sæt af færdigheder og kompetencer, som gør det muligt for dem at opnå fælles mål eller gennemføre fælles projekter (Lipponen, 2010, s. 55f; Wenger, 1998).

\section{Diskursive vinkler på informationskompetence og Kritisk padagogik}

Diskursteorier undersøger forståelser af informationspraksisser fra et historisk/sociologisk perspektiv (Limberg et al., 2012, s. 95) og den sociale og kulturelt formede måde at forstå informationspraksisser på. Diskursanalytikere er ikke så meget interesseret i hvad folk gør, men ser i stedet for på de interpretative repertoires, gennem hvilke mennesker giver mening til disse informationspraksisser (Limberg et al., 2012, s. 110). Fx undersøges, hvordan professionelle agenter ( $\mathrm{fx}$ bibliotekarer, informationsspecialister, informationsvidenskabelige forskere, ...) karakteriserer informationsbrugernes kompetencer: Beskrives brugere som ikke-vidende individer med en mangel/ et behov, og nedtones i denne "farvede" diskurs menneskenes ofte skabende rolle i forhold til information? Et af resultaterne af diskursanalytisk forskning er, at det er selve den bibliotekariske diskurs, som danner (billedet af) den "information poor" (Limberg et al., 2012, s. 111).

Grundlæggeren af diskursanalyse, Michel Foucault, opfattede diskurser som "systems of statements that systematically form the object of which they speak" (Limberg et al., 2012, s. 111). Diskurser er vidensformationer i egentlig forstand: påstande, der er forbundet med og henviser til hinanden, antagelser, som forudsættes og dermed konsolideres, og meninger, som læner sig op ad andres mening eller en autoritet. Dette netværk er forbundet og gives kohærens gennem en specifik og forenende linse, sådan at diskurser kun leverer et delvist, pseudo-ikke-fragmenteret og begrænset perspektiv på vidensproduktion. I analyser af informationskompetence er det derfor vigtigt at identificere denne specifikke optik/diskursspecifikke vinkel og bringe alle baggrundsantagelser frem i lyset, som styrer og ligger til grund for diskussioner omkring informationskompetence (Limberg et al., 2012, s. 111).

Et nøglebegreb for diskursanalyse er magt, ikke bevidst udøvet som et individuelt fænomen, men placeret i dens historiske sammenhæng: den "magt"fulde indflydelse af historiske former på tænkning og de etablerede diskurser, som påvirker og styrer mennesker, mens de ydre betingelser ændrer sig hele tiden (Limberg et al., 2012, s. 117). Især disse sidste bemærkninger peger i retning af, at diskursanalytiske antagelser tager en radikal vending i forhold til de nævnte integrative kriterier af informationskompetenceteorier. Individuelle erfaringer (b) mister deres relevans $i$ et stort univers af magtfulde diskurser og former, som overfører personlige og skiftende konceptioner i en fast struktur, ordnet under en overordnet paraply af diskurser. Variation af situationelle aspekter (a) er ligeså opfanget i en overordnet udvikling af historiske faser og teknologiske revolutioner.

Læring derimod tilkommer på trods - eller netop pga. nedtoningen af de to integrative kriterier - en afgørende rolle i diskursanalytisk tænkning, også mht. informationskompetence: Gennem bevidstgørelse af dominerende diskurser med deres implicitte antagelser og ubeviste påstande destabiliseres magtfulde holdninger, og andre perspektiver og sandheder kommer til syne, således at der kan opstå nye forståelser af informationskompetence (Limberg et al., 2012, s. 114). Læring i diskursanalytiske termer er 
den erkendelse, at "[...] implicit cultural orders and assumptions guide teaching practices" (Limberg et al., 2012, s. 116).

Mens diskursanalyse sætter spørgsmålstegn ved (åbenbart) "gyldige" begreber af informationskompetence, som så indirekte, $i$ et andet skridt, virker destabiliserende på gængse og anerkendte undervisningspraksisser, ridser Kritisk pædagogik, en beslægtet retning af diskursanalytisk teori, konkrete mål og konkrete indholdsmæssige elementer op for en informationskompetenceundervisning og -læring, som udfordrer de dominerende diskurser. Kritisk pædagogik, som korresponderer med det omtalte "transformative vindue", efterlyser, nu i Kritisk teoris jargon, på baggrund af Lyotard, mere individuelle, fragmenterede fortællinger, som retter blikket væk fra de store, "naturlige" forklaringer af virkeligheden hen til de mange forskellige "stemmer" "på den anden side" (Franks, 2010, s. 43). Der forudsiges et sammenbrud af den store fortælling, fremskyndet af internettet og den nye tilgængelighed af information, der er forbundet med det. Ifølge kritiske pædagoger vanker der en befriende postmoderne pædagogik, hvor alle discipliner skal stille sig kritiske ved deres måder at konstruere viden på (Franks, 2010, s. 44). Der hersker, ifølge Kritisk pædagogik, stor faglig isolation, således at specialister ofte søger ud på andre områder og derved skaber tværfaglighed. Det bidrager til at udfordre de store fortællinger, som er knyttet til de historiske fag og til den traditionelle disciplinære opdeling. Tværfaglighed er den største udfordring for et fags store fortællinger (Franks, 2010, s. 45).

Dermed er genstand for læring fra en kritisk vinkel indkredset: Studerende skal lære at identificere de andres stemme, som ikke er repræsenteret i de store fortællingers materialer, og lære, at alle tekster, altså også dem, der er kritiske over for de store fortællinger, skal mødes på en kritisk måde. Metoden til at opnå denne læring er en refleksiv tilgang (Franks, 2010, s. 46), hvor den rådgivende bibliotekar/infor- mationsspecialist tilkommer en vigtig rolle: Hvilke kilder skal der anbefales til de studerende og hvordan kan de hjælpes på vej til at løse sig fra deres fags begrænsninger og problemer? Det bliver også fremhævet af den Kritiske pædagogiks vinkel, at informationskompetencestandarderne er særdeles uegnede til at skaffe en "kritisk bevidsthed", som kun opstår, hvis reale problemer diskuteres i en åben dialog. Problembaseret læring er her et godt alternativ, hvor også bibliotekaren har mulighed for at træde ind i en læringsorienteret dialog med de studerende (Kopp \& Olson-Kopp, 2010, s. 58-61).

\section{Sammenfatning af resultater}

Nedenstående tabel sammenfatter undersøgelsens resultater i skematisk form.

Tabellen viser en aftagning af integrative kriterier fra fænomenografien, som realiserer begge kendetegn, til sociokulturelle/praksisteoretiske tilgange, som alene fokuserer på situation, og nedtoner hermed rollen af den lærendes individuelle erfaring. Diskursanalytiske tilgange og Kritisk pædagogik situerer individuelle erfaringer og situationelle kontekster i en tilbageliggende, overordnet "kode", som først "skaber" de ting, vi taler om, ligesom den præger den måde, vi italesætter dem. Diskursanalytisk-kritiske holdninger over for læring - under den specifikke betingelse af situationens og individets fravær i den teoretiske modellering - kan nok bedst forstås ved at stille dem over for sociokulturelle/praksisteoretiske synspunkter på læring. Begge projekter har modsatte ambitioner i forhold til hinanden, idet praksisteoretiske tilgange til læring fremhæver, ganske konservativt, læringens konventionelle karakter og stabilisering gennem udøvelse og aktivitet i vedtagne praksisser, mens kritiske tilgange til læring netop retter sig imod overvindelse af disse "praktiske bånd", gennem bevidst refleksion (især diskursteori) og en grundlæggende kritisk holdning til al information (i særdeleshed Kritisk pædagogiks mål).

\begin{tabular}{|l|l|l|l|}
\hline Integrative kriterier & $\begin{array}{l}\text { Fænomenografiske } \\
\text { tilgange }\end{array}$ & $\begin{array}{l}\text { Sociokulturelle og praksis- } \\
\text { teoretiske tilgange }\end{array}$ & $\begin{array}{l}\text { Diskursanalytiske tilgange } \\
\text { og Kritisk pædagogik }\end{array}$ \\
\hline Situation/kontekst (a) & $\mathrm{X}$ & $\mathrm{X}$ & - \\
\hline Individuel erfaring (b) & $\mathrm{X}$ & - & - \\
\hline
\end{tabular}

Tabel 1. Tre tilgange til lcering og informationskompetence, og teoriernes fokus på de to integrative kriterier situation (a) og erfaring (b) 


\section{Nogle praktiske slutbemærkninger}

Med indtog af integrative elementer i informationskompetencekonceptet er der sket et skift fra et præskriptivt sæt af færdigheder til deskriptionen af "informationsrelaterede aktiviteter", der principielt og i første række knytter sig til andre, direkte læringsrelaterede aktiviteter. Sidstnævnte danner overordnede sammenhæng, er integrative, motiverer og giver derved retning og mening til den enkeltes informationsadfærd, der ellers ville stå alene og uden virkeligt mål (Lupton, 2008, s. 35). Informationskompetence, set ud fra dette aktivitetsbaserede syn på en kompleks handling, er en læringsrelateret praksis, da den er del af en anden læringsrelateret praksis, fx at løse et problem eller studere på et universitet. Informationskompetence, udøvet i en kontekst af højere uddannelser, "arver" derved læringskontekst og relevans for læring fra den overordnede institutionelle læringsaktivitet, som den er del af - og vævet sammen med.

Det åbner for muligheden af at drage forskellige forbindelseslinjer mellem det teoretiske plan, hvor læringsaspektet stærkt har influeret informationskompetencebegrebet, og det praktiske plan, hvor informationskompetence i dag i høj grad indgår i den formelle uddannelse i form af programmer, studieordninger på universiteter og uddannelsesinstitutionernes præsentationer på nettet (Bawden, 2001, s. 232; Engerer \& Thestrup, 2009). Set ud fra bibliotekernes perspektiv kan integrative komponenter af informationskompetence og læring bidrage til en bedre forståelse af bibliotekets undervisningstiltag $\mathrm{i}$ informationskompetence og samtidig hjælpe til at reformulere nogle formidlingsmæssige udfordringer for forskningsbiblioteker som strategisk agerende organisationer, der skal leve op til deres mission i forhold til de universitære kunder.

Integrative tiltag inden for informationskompetence og læring, både på det teoretisk centrale fænomenografiske område (vinduestilgang, Bruces forskning og Luptons læringsperspektiv) og inden for de her også belyste sociokulturelle og diskursteoretiske tilgange, har visse præferencer for bestemte læringsmåder tilfælles - fx vil alle teorier gå ind for problembaseret-opgaveorienteret og situeret læring samt igangsættelse af kognitive refleksioner hos den lærende. Det må vise sig i fremtiden, hvordan disse teoretiske vendinger omsættes og formidles til infor- mationsspecialister og andre praktikere (se Julien \& Williamson, 2011).

Hvad teoriernes forhold til læring og deres integrative tendenser angår, kan det dog konstateres, at alle grene gør læring til et konstitutivt element af deres teoretiske bestræbelser, idet informationsbrug og læringsprocesser betragtes, helt i overensstemmelse med den integrative tese, som tæt sammenhængende størrelser, og begge hører i dag hjemme i et moderne koncept af informationskompetence (Kari \& Savolalinen, 2010, s. 229). ${ }^{7}$

\section{Noter}

1. Jeg vil takke Diana Bie, studiesekretær på Det Informationsvidenskabelige Akademi i Aalborg, som tilrettede mine grammatiske fordrejninger og fortyskede konstruktioner. En sidste rettelse foretog Adda Salomonsen, bibliotekar på Hjørring Bibliotek. Alle resterende fejl, uklarheder og andet vrøvl i denne artikel står jeg alene inde for

2. I denne sammenhæng nævnes tit begreberne "livslang læring" og den "selvhjulpne bruger" (Bawden, 2001, s. 233; Grassian \& Kaplowitz, 2009, s. 4-7, 267f; Sinkinson \& Lingold, 2010, s. 87 ud fra den Kritiske pædagogik), som forudsætter tilegnelse/besiddelse af generelle færdigheder omkring information og læring. Undervisning i informationskompetence er i dette perspektiv ikke en fortsættelse af formidling af bibliotekets ressourcer, men et forsøg på at uddanne folk til selv at kunne finde og håndtere information til at løse problemer, og træffe beslutninger nu og i fremtiden (Pinto, Cordón, \& Gómez Díaz, 2010, s. 4).

3. I Informationsordbogen (Udgiverselskabet Informationsordbogen, 2012-) fx bliver man med en enkel søgning "læring" ført hen til en specielt oprettet emne-"klynge" med titlen "Informationskompetence og læring". De her samlede 104 termer (11.7.2012) rækker fra "adfærdsteori" til "øveprogram" og viser klart, hvor sammenflettede informationskompetence og læring opfattes i bibliotekssammenhæng.

4. http://www.ala.org/acrl/publications/whitepapers/ presidential. Derudover findes også mindre tit omtalte standarder som fx SCONUL (DaCosta, 2011, s. 35). 
5. Konstruktivistiske læringsteorier er centrale i forhold til informationskompetence, bl.a. fordi de er velegnede til at knytte det veludforskede begreb 'informationssøgning' ('information seeking'), som har en lang historie i informationsvidenskaben, til den lidt udenfor liggende forskning omkring informationskompetence (Julien \& Williamson, 2011). Dog skal der siges, at konstruktivistiske syn på læring ikke er fraværende i de præsenterede analyser, fænomenografien, som er udførligt behandlet her, baserer sig i stor grad på konstruktivistiske ideer (Limberg et al., 2012, s. 102).

6. Generelt var de studerende sig bevidst over sammenhæng mellem information og den disciplinære læring (Bruce \& Hughes, 2010, s. A6), samtidig med at de fx lærte at bruge en ny tidsskriftdatabase, lavede de også aktiv research i et emne (Bruce \& Hughes, 2010, s. A7): "It is simultaneous attention to both information use and learning which is the key ingredient of the informed learning concept ...".

7. I en undersøgelse om, hvordan forholdet mellem informationsbrug og læring beskrives i den informationsvidenskabelige litteratur, finder Kari \& Savolalinen (2010, s. 235) frem til følgende relationer: a) læring er en del af informationsbrug, b) informationsbrug er en del af læring, c) læring påvirker informationsbrug, d) informationsbrug påvirker læring, e) informationsbrug og læring interagerer. Det viser på den ene side, hvor uklart det teoretiske forhold mellem information og læring er, men på den anden side påpeger de fem ovennævnte relationer også, at de to størrelser hænger sammen (der findes ingen kategori, som eksplicit nægter en sammenhæng mellem informationsbrug og læring) (Kari \& Savolalinen, 2010, s. 243).

\section{Referencer}

Bawden, D (2001). Information and digital literacies: A review of concepts. Journal of Documentation, 57(2), 218-259.

Bruce, C (1998). The phenomenon of information literacy. Higher Education Research \& Development, 17(1), 25-43.

Bruce, C \& Hughes, H (2010). Informed learning: A pedagogical construct attending simultaneously to information use and learning. Library \& Information Science Research, 32(4), A2-A8.

DaCosta, JW (2011). Information literacy in the digital environment. I: P. Dale, J. Beard \& M. Holland (Eds.), University libraries and digital learning environments (s. 33-47). Farnham: Ashgate.

Engerer, V \& Stadsgaard, I (2011). Hurtig navigation gennem informationshavet. DF Revy, 34(1), 4-5.

Engerer, V \& Thestrup, JB (2009). Informationskompetence på biblioteket, på universitetet og imellem. Arbejdspapirer Fra Center for Undervisningsudvikling, 2, 7-30.

Franks, S (2010). Grand narratives and the information cycle in the library instruction classroom. I: M. T. Accardi, E. Drabinski \& A. Kumbier (Eds.), Critical library instruction. theories \& methods (s. 43-54). Duluth, Minnesota: Library Juice Press.

Grassian, ES \& Kaplowitz, JR (2009). Information literacy instruction: Theory and practice (2nd ed.). New York: Neal-Schuman Publishers.

Julien, H \& Williamson, K (2011). Discourse and practice in information literacy and information seeking: Gaps and opportunities. Information Research, 16(1), 11 sider.

Kari, J \& Savolalinen, R (2010). On the connections between information use and learning process. I: A. Lloyd, \& S. Talja (Eds.), Practising information literacy: Bringing theories of learning, practice and information literacy together (s. 229-249). Wagga Wagga, N.S.W.: Centre for Information Studies, Charles Sturt University.

Kautto, V \& Talja, S (2007). Disciplinary socialization: Learning to evaluate the quality of scholarly literature. Advances in Library Administration and Organization, 25, 33-59.

Kopp, BM \& Olson-Kopp, K (2010). Depositories of knowledge: Library instruction and the development of critical consciousness. I: M. T. Accardi, E. Drabinski \& A. Kumbier (Eds.), Critical library instruction. theories \& methods (s. 55-67). Duluth, Minnesota: Library Juice Press. 
Kuhlthau, CC (2004). Seeking meaning: A process approach to library and information services (2nd ed.). Westport/Connecticut, London: Libraries Unlimited.

Lave, J \& Wenger, E (1991). Situated learning: Legitimate peripheral participation. Cambridge: Cambridge University Press.

Limberg, L, Sundin, O \& Talja, S (2012). Three theoretical perspectives on information literacy. Human It, 11, 93-130.

Lindquist, T \& Long, H (2011). How can educational technology facilitate student engagement with online primary sources? A user needs assessment. Library Hi Tech, 29(2), 224-241.

Lipponen, L (2010). Information literacy as situated and distributed activity. I: A. Lloyd \& S. Talja (Eds.), Practising information literacy: Bringing theories of learning, practice and information literacy together (s. 51-64). Wagga Wagga, N.S.W.: Centre for Information Studies, Charles Sturt University.

Littlejohn, A (2005). Key issues in the design and delivery of technology-enhanced learning. I: P. Levy, \& S. Roberts (Eds.), Developing the new learning environment: The changing role of the academic librarian (s. 70-90). London: Facet Publishing.

Lupton, M (2008). Information literacy and learning. Adelaide: Auslib Press.

Lupton, M \& Bruce, C (2010). Windows on information literacy worlds: Generic, situated and transformative perspectives. I: A. Lloyd \& S. Talja (Eds.), Practising information literacy: Bringing theories of learning, practice and information literacy together (s. 3-27). Wagga Wagga, N.S.W.: Centre for Information Studies, Charles Sturt University.

Marton, F \& Booth, S (1997). Learning and awareness. New York, London: Routledge.

Owusu-Ansah, EK (2003). Information literacy and the academic library: A critical look at a concept and the controversies surrounding it. The Journal of Academic Librarianship, 29(4), 219-230.
Peacock, J (2005). Information literacy education in practice. I: P. Levy \& S. Roberts (Eds.), Developing the new learning environment: The changing role of the academic librarian (s. 153-180). London: Facet Publishing.

Pinto, M, Cordón, JA \& Gómez Díaz, R (2010). Thirty years of information literacy (1977-2007). Journal of Librarianship and Information Science, 42(1), 3-19.

Schreiber, T (2011). Informationskompetence. Set ud fra to forskellige praksisteorier. Dansk Biblioteksforskning: Tidsskrift for Informations- og Kulturformidling, 7(2/3), 95-107.

Sinkinson, C \& Lingold, MC (2010). Re-visioning the library seminar through a lens of critical pedagogy. I: M. T. Accardi, E. Drabinski \& A. Kumbier (Eds.), Critical library instruction. Theories \& methods (s. 81-88). Duluth, Minnesota: Library Juice Press.

Udgiverselskabet Informationsordbogen. (2012-). Informationsordbogen: Ordbog for informationshåndtering, bog og bibliotek. Udgiverselskabet Informationsordbogen.

Walton, G \& Hepworth, M (2011). A longitudinal study of changes in learners' cognitive states during and following an information literacy teaching intervention. Journal of Documentation, 67(3), 449-479.

Wenger, E (1998). Communities of practice: Learning, meaning and identity. Cambridge: Cambridge University Press.

Williams, D (2005). Literacies and learning. I: P. Levy \& S. Roberts (Eds.), Developing the new learning environment: The changing role of the academic librarian (s. 49-69). London: Facet Publishing.

Woolwine, DE (2010). Generic versus disciplinespecific skills. I: A. Lloyd \& S. Talja (Eds.), Practising information literacy: Bringing theories of learning, practice and information literacy together (s. 169-188). Wagga Wagga, N.S.W.: Centre for Information Studies, Charles Sturt University. 